\title{
Barking up the wrong tree: Modern northern European dogs fail to
} explain their origin

\author{
Helena Malmström*1, Carles Vilà ${ }^{1}$, M Thomas P Gilbert ${ }^{3}$, Jan Storå4, \\ Eske Willerslev $^{3}$, Gunilla Holmlund ${ }^{2}$ and Anders Götherström ${ }^{1}$
}

\begin{abstract}
Address: ${ }^{1}$ Department of Evolutionary Biology, Uppsala University, SE-752 36 Uppsala, Sweden, ${ }^{2}$ National Board of Forensic Medicine, Department of Forensic Genetics and Forensic Toxicology, Linköping, Sweden, ${ }^{3}$ Centre for Ancient Genetics, Biological Institute, University of Copenhagen, Denmark and ${ }^{4}$ Osteoarchaeological Research Laboratory, Stockholm University, Stockholm, Sweden

Email: Helena Malmström* - hmalmstrom@bi.ku.dk; Carles Vilà - carles.vila@ebc.uu.se; M Thomas P Gilbert - mtpg@bi.ku.dk; Jan Storå - jan.stora@ofl.su.se; Eske Willerslev - ewillerslev@bi.ku.dk; Gunilla Holmlund - gunilla.holmlund@rmv.se;

Anders Götherström - anders.gotherstrom@ebc.uu.se

* Corresponding author
\end{abstract}

Published: 28 February 2008

BMC Evolutionary Biology 2008, 8:7| doi:|0.| |86/|47|-2|48-8-7|
Received: 5 July 2007

Accepted: 28 February 2008

This article is available from: http://www.biomedcentral.com/|47|-2/48/8/7I

(C) 2008 Malmström et al; licensee BioMed Central Ltd.

This is an Open Access article distributed under the terms of the Creative Commons Attribution License (http://creativecommons.org/licenses/by/2.0), which permits unrestricted use, distribution, and reproduction in any medium, provided the original work is properly cited.

\begin{abstract}
Background: Geographic distribution of the genetic diversity in domestic animals, particularly mitochondrial DNA, has often been used to infer centers of domestication. The underlying presumption is that phylogeographic patterns among domesticates were established during, or shortly after the domestication. Human activities are assumed not to have altered the haplogroup frequencies to any great extent. We studied this hypothesis by analyzing $24 \mathrm{mtDNA}$ sequences in ancient Scandinavian dogs. Breeds originating in northern Europe are characterized by having a high frequency of $m t D N A$ sequences belonging to a haplogroup rare in other populations $(\mathrm{HgD})$. This has been suggested to indicate a possible origin of the haplogroup (perhaps even a separate domestication) in central or northern Europe.
\end{abstract}

Results: The sequences observed in the ancient samples do not include the haplogroup indicative for northern European breeds $(\mathrm{HgD})$. Instead, several of them correspond to haplogroups that are uncommon in the region today and that are supposed to have Asian origin.

Conclusion: We find no evidence for local domestication. We conclude that interpretation of the processes responsible for current domestic haplogroup frequencies should be carried out with caution if based only on contemporary data. They do not only tell their own story, but also that of humans.

\section{Background}

Mitochondrial phylogeography is a useful tool for the study of wild populations [1]. But applying phylogeography to domestic species is more complicated. For example, the arrival of dogs into the New World was not a simple expansion of Asian dog populations, but a consequence of human migrations [2]. Humans have a history of population movements and social changes over the last ten thousand years [3-6], and this, together with the human-mediated breeding history has affected the genetic composition of livestock animals [7]. Therefore, human influence cannot be neglected when studying patterns of genetic diversity in domesticates. 
A classic example of the use of mitochondrial DNA (mtDNA) diversity to infer the history of domestication refers to dogs (Canis familiaris). Four to six mitochondrial haplogroups $(\mathrm{Hg})$ have been described in genetic studies of modern dogs [8], indicating recurrent domestication or backcrosses between domestic dogs and wild wolves (Canis lupus). Three of the major Hgs are distributed throughout the world, whereas one (D) is restricted to Europe, especially in breeds originating in Scandinavia [811]. Similar patterns of fragmented genetic diversity have been used to argue for local domestication in other species [12]. Such scenario could apply to dogs as they appear as early as 9000 years ago in Scandinavia $[13,14]$, and as dogs and wolf remains have been found on the same sites $[15,16]$.

We have genetically typed mtDNA from ancient Scandinavian dog remains to investigate whether the high frequency of a rare dog $\mathrm{Hg}$ in northern Europe is evidence of a local domestication event. We predict that an early domestication event in Scandinavia would be visible in a notable frequency of Hg D in ancient Scandinavian dog remains.

\section{Results and Discussion}

Reproducible sequence data for the full 219 bp sequence was recovered from 18 samples. The remaining six specimens only yielded reproducible sequence data for a shorter 107 bp product (DQ860843-3 DQ860864, AY673648-AY673672, Table 1). Phylogenetic reconstruction including the 18 prehistoric dogs that yielded complete sequences and 543 modern dog sequences [11] revealed that all prehistoric dogs grouped within modern Hgs (Figure 1). Seven of the 18 sequences belonged to $\mathrm{Hg}$ A, the group that encompasses more than $70 \%$ of all tested modern dogs around the world [11], while the remaining eleven belonged to the now rare $\mathrm{Hg}$ C. Previously published data on 273 Swedish dogs indicated frequencies of the four major Hgs: A $69.2 \%$, B $18.3 \%$, C $7.0 \%$, and D 5.5\% [9]. When only native Scandinavian breeds were considered $(n=54)$, the haplotype frequency for Hg D increased to 33.3\% [9]. A comparison of the 219 bp sequences obtained from the ancient dog specimens ( $\mathrm{n}$ $=18$ ) and the contemporary native breeds indicates that the frequency of $\mathrm{Hg} \mathrm{D}$ is significantly reduced in the ancient data set $(0 \%$ in the ancient dataset, 33\% in the modern dataset, $\mathrm{p}<0.001)$. The remaining six ancient Scandinavian dogs that yielded only $107 \mathrm{bp}$ of reproducible sequence data, also indicated an absence of $\mathrm{Hg} \mathrm{D}$ (Table 2). In total, eleven sequences had substitution patterns indicative for $\mathrm{Hg} \mathrm{A}$, while the remaining 13 had a substitution indicative for $\mathrm{Hg} \mathrm{C}$ (Table 1 ).

When the complete ancient dataset was compared to the contemporary dataset, it proved equally improbable $(\mathrm{p}<$
Table I: Description of material and $\mathrm{Hg}$ belonging.

\begin{tabular}{|c|c|c|c|c|}
\hline Sample & Locality & Element & Age & Haplogroup \\
\hline $2^{1,2}$ & Korsnäs\# & Bone & Neolithic & C \\
\hline 31 & Korsnäs\# & Bone & Neolithic & $A^{*}$ \\
\hline $4^{1,2}$ & Korsnäs\# & Bone & Neolithic & $A$ \\
\hline $12^{1,3}$ & Bergsgraven & Bone & Neolithic & C \\
\hline 131,2 & Ajvide & Bone & Neolithic & $\mathrm{C}$ \\
\hline $\mid 5^{1,2}$ & Ajvide\# & Bone & Neolithic & $\mathrm{C}$ \\
\hline 161,2 & Ajvide $\#$ & Bone & Neolithic & $A$ \\
\hline $17^{1,2}$ & Ajvide & Bone & Neolithic & $\mathrm{C}$ \\
\hline $18^{1,2}$ & Ajvide & Bone & Neolithic & $\mathrm{C}$ \\
\hline 191,2 & Ajvide\# & Bone & Neolithic & $\mathrm{C}$ \\
\hline $21^{1,2}$ & Ajvide & Teeth & Neolithic & $\mathrm{C}$ \\
\hline $22^{1,2}$ & Ajvide \# & Teeth & Neolithic & $\mathrm{C}$ \\
\hline $23^{1,2}$ & Ajvide & Teeth & Neolithic & $\mathrm{C}$ \\
\hline $25^{1,3}$ & Ajvide & Tooth & Neolithic & $\mathrm{C}$ \\
\hline 261,3 & Skara A & Bone & Medieval & $A^{*}$ \\
\hline $27^{1,2}$ & Skara B & Bone & Medieval & $A$ \\
\hline 281 & Stockholm & Bone & Medieval & $C^{*}$ \\
\hline $30^{2,3}$ & Visby & Teeth & Neolithic & $A$ \\
\hline $32^{3}$ & Eketorp & Bone & Medieval & $C^{*}$ \\
\hline $33^{3}$ & Eketorp & Bone & Medieval & $A^{*}$ \\
\hline $34^{3}$ & Eketorp & Bone & Medieval & $A^{*}$ \\
\hline $1243^{3}$ & Sunnerby & Tooth & Medieval & $A$ \\
\hline 2293 & Sunnerby & Bone & Medieval & $A$ \\
\hline $231^{3}$ & Sunnerby & Bone & Medieval & $A$ \\
\hline
\end{tabular}

Scandinavian dog remains yielding DNA. Sample name, locality, element (tooth or bone), age, and haplogroup are specified. Those independently replicated are marked with \#, those only yielding the 107 bp fragment are marked with * (otherwise, the total length of the studied sequence is $219 \mathrm{bp}$ ). Sequences are from Malmström et al $2005^{\prime}$ ( 107 bp), Malmström et al $2007^{2}$ (I I 2 bp), and from this study ${ }^{3}$ (either or both fragments).

0.001) that Hg D was present in the oldest specimens in a frequency similar to that observed in modern dogs. Using a binomial distribution, we estimate that the frequency of Hg D must have been lower than 0.118 in the original population for us not to have noticed it in 24 samples ( $\mathrm{p}$ $<0.05$ ), and lower than 0.182 during the Neolithic for us not to have noticed it in 15 samples $(\mathrm{p}<0.05)$. Lastly, the $\chi 2$ test between the $\mathrm{Hg}$ frequencies of the complete ancient dataset with that of the complete Scandinavian (not only considering native breeds) demonstrated a significant deviation between the modern and ancient frequencies $\left(\mathrm{p}<0.0388, \chi^{2}=4.27, \mathrm{df}=1\right)$.

Our results indicate that $\mathrm{Hg}$ frequencies have been altered in Scandinavian dogs since their first arrival. Interestingly, while $\mathrm{Hg} \mathrm{C}$ is overrepresented in our ancient material, there is a complete lack of the Scandinavian group D in our ancient dataset. Hg D is the one that could support a Scandinavian origin whereas $\mathrm{Hg} \mathrm{C}$ is suggested to be of Asian origin [11]. Thus, we find no obvious evidence for prehistoric canid domestication in Scandinavia. An external origin of Scandinavian dogs is supported by morphologic data, as even the oldest remains of dogs in 
Table 2: Description of genetic data.

\begin{tabular}{|c|c|c|c|c|c|c|c|c|c|c|}
\hline & 15595 & 15611 & 15625 & 15626 & 15638 & 15639 & 15650 & 15652 & 15665 & $\mathrm{Hg}$ \\
\hline Ref & C & $\mathbf{T}$ & $\mathbf{T}$ & A & $T$ & $\mathbf{T}$ & $T$ & G & $\mathbf{T}$ & - \\
\hline 2 & . & . & . & & G & . & C & . & 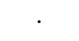 & C \\
\hline 3 & . & . & . & . & A & . & . & . & C & A \\
\hline 4 & . & . & . & G & A & . & . & . & C & A \\
\hline 12 & . & . & . & . & G & . & c & . & . & C \\
\hline 13 & . & C & . & . & G & . & c & . & . & C \\
\hline 15 & . & C & . & . & G & . & c & . & . & C \\
\hline 16 & . & . & . & . & A & . & & . & C & A \\
\hline 17 & . & C & . & . & G & . & c & . & . & C \\
\hline 18 & . & C & . & . & G & . & C & . & . & C \\
\hline 19 & . & C & . & . & G & . & C & . & . & C \\
\hline 21 & . & C & . & . & G & . & c & . & . & C \\
\hline 22 & . & C & . & . & G & . & C & . & . & C \\
\hline 23 & . & C & . & 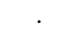 & G & . & c & . & . & C \\
\hline 25 & . & C & . & . & G & . & C & . & . & C \\
\hline 26 & . & . & . & G & A & . & . & . & . & A \\
\hline 27 & . & . & . & G & A & . & . & . & . & A \\
\hline 28 & . & C & . & 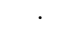 & G & . & C & . & . & C \\
\hline 30 & . & . & . & . & A & . & 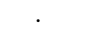 & . & C & A \\
\hline 32 & . & C & . & . & G & . & C & . & . & C \\
\hline 33 & . & . & . & G & A & . & . & . & . & A \\
\hline 34 & . & . & . & . & A & . & . & . & . & A \\
\hline 1243 & . & . & . & . & . & . & . & . & . & A \\
\hline 229 & . & . & . & . & . & . & . & . & . & A \\
\hline 231 & . & . & . & & . & . & . & . & . & A \\
\hline
\end{tabular}

Haplogroup-specific substitutions in a 107 bp fragment of the D-loop (I556I-15668) and their occurrence in 24 ancient Scandinavian dogs. The reference sequence is from Kim et al. 1998.

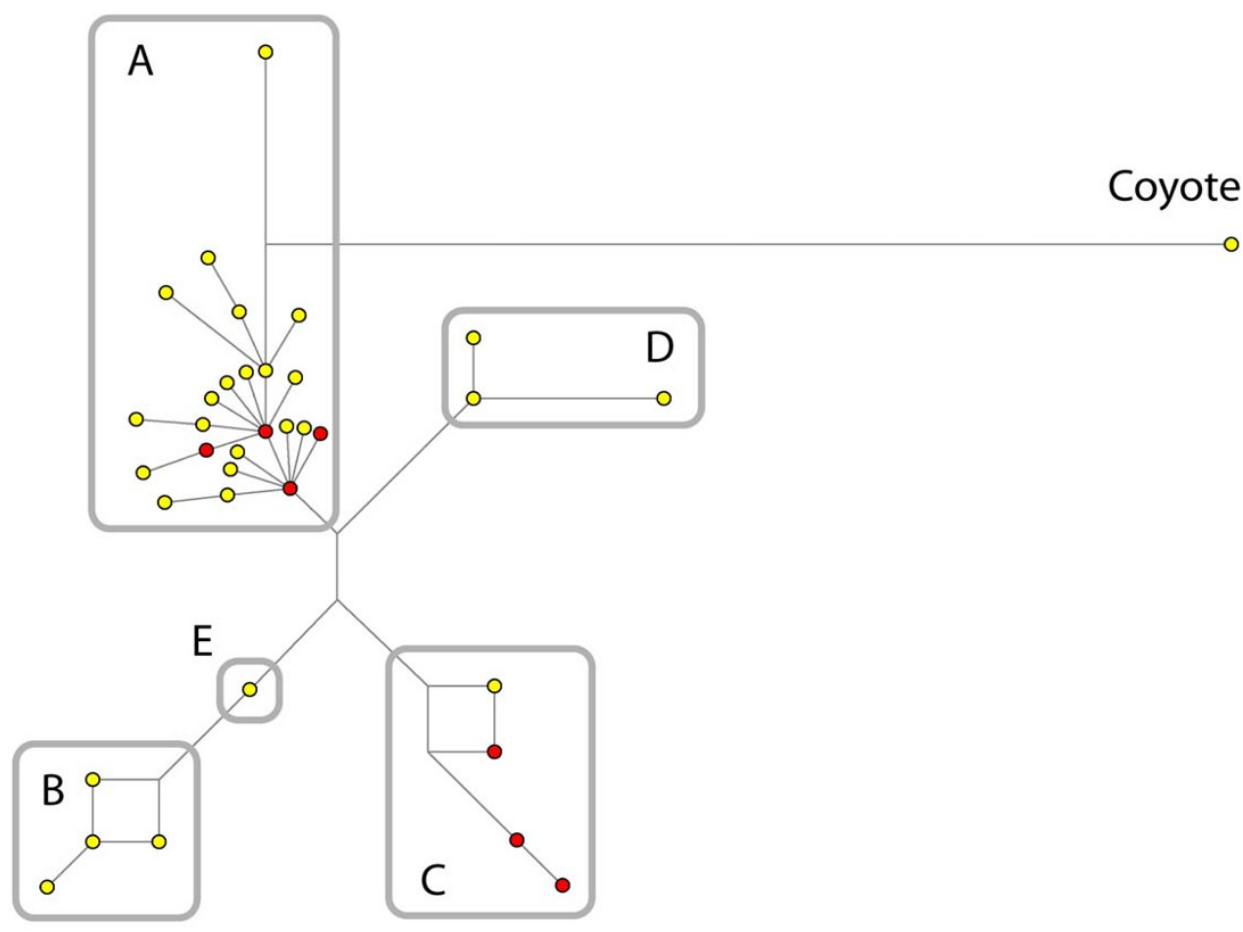

Figure I

Reduced median network based on 56 I sequences (2 I6 bp in length) including 18 ancient sequences (full sequences, not only those in Table 2 ) produced in this study and a coyote (Canis latrans) outgroup. After removing tri-status characters, 36 haplotypes remain; those in red contain at least one ancient Scandinavian individual. A NJ tree based on Kimura-2 and bootstrapped with 1000 pseudoreplicates yielded a similar topology where $\mathrm{Hg} A$ was not supported, $\mathrm{Hg} \mathrm{B}$ received $81 \%$ support, $\mathrm{Hg} \mathrm{C} \mathrm{84 \% ,} \mathrm{and} \mathrm{Hg} \mathrm{D} 65 \%$. Four medieval and three Neolithic dogs are distributed among the $\mathrm{Hg}$ A sequences, and II Neolithic sequences are distributed within the $C$ clade. 


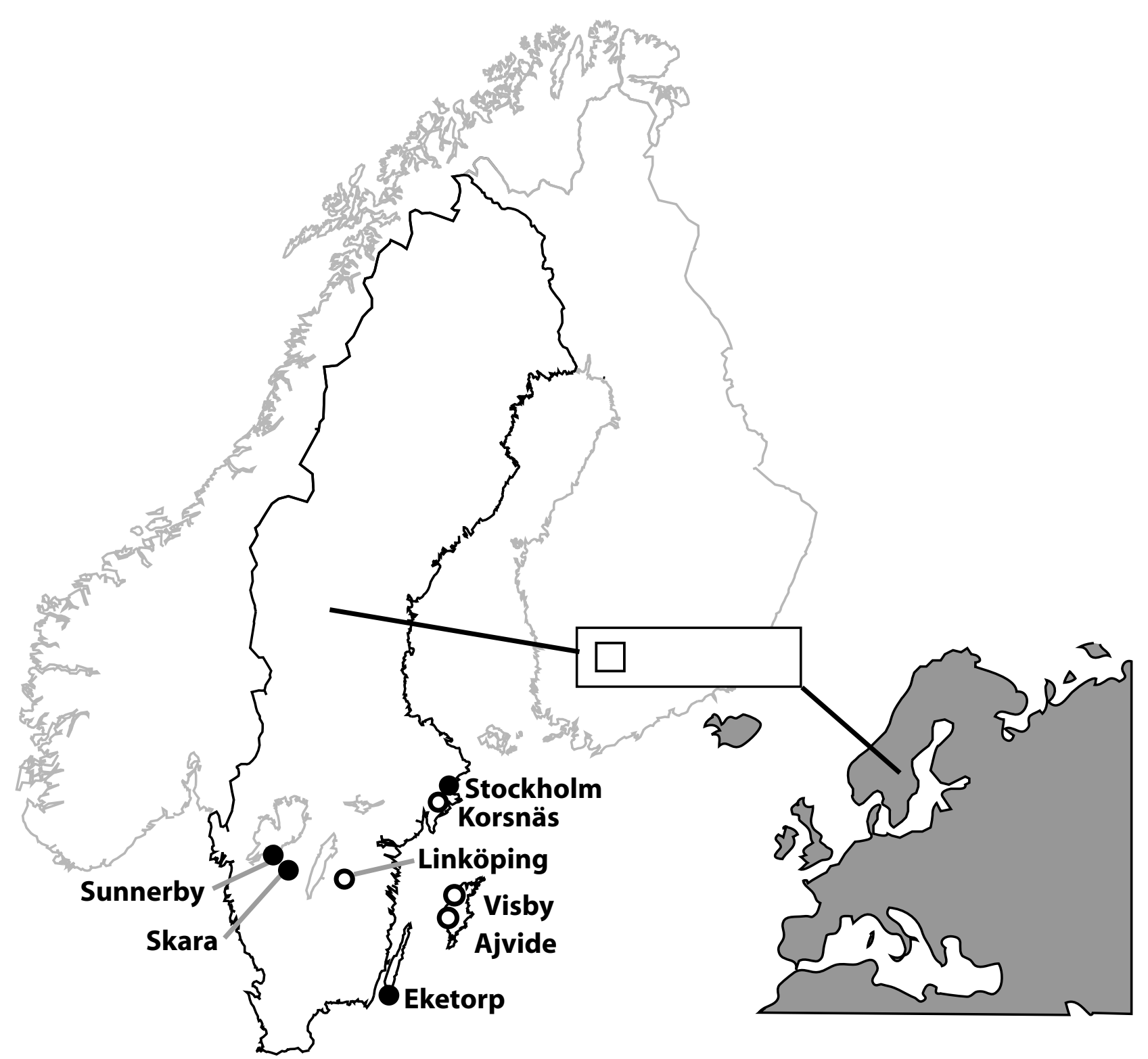

Figure 2

Samples were collected from eight different archaeological localities in southern Scandinavia, four Neolithic (empty circles) and four medieval (black dots).

Scandinavia were of smaller size than those of prehistoric and extant wolves $[15,17]$. While canid domestication may have occurred in other parts of Europe [18], Scandinavian dogs were likely imported and had experienced a long period of morphological change under human control before they reached the Scandinavian peninsula.

\section{Conclusion}

In a wider context, our data calls for caution when using modern sequences of domestic animals to interpret the history of domestication. There is a profound difference on selective forces on wild and domestic animals. Domesticates are subject to constant manipulation and follow the same historic vicissitudes as the associated human population. For example, genetic diversity may change rapidly due to intense selective breeding, backcrossing with the wild ancestor [19-22], migration of human groups with genetically different domesticates [2], and decimation of local populations by invaders [23]. Hg frequency could change over a short period of few genera- 
tions. While diversity and branching pattern of mitochondrial DNA may be used to study the number and possible antiquity of domestication events, phylogeographical patterns in domestic species may indeed not be suitable to base discussion on their geographical origin. Close collaboration between zooarchaeologists and molecular biologists, involving the study of ancient specimens, may be the only way to verify the continuity through time of the species that have set the basis of our culture.

\section{Methods}

We analysed sequences from 24 archaeological domestic dogs. The skeletal material represents eight Scandinavian sites: four Neolithic ( $\approx 5300-4500 \mathrm{BP}$ ) and four Medieval ( $\approx 1000-500$ BP) (Table 1, Figure 2). DNA was extracted, PCR-amplified and sequenced according to previously published protocols [24,25] (Table 1). A subset of the sample sequences $(n=7)$ was replicated in an independent laboratory (Center for Ancient Genetics, University of Copenhagen) confirming the original results in all cases. The new data was combined with previously published data $[24,25]$ for analysis (see Table 1). Most of the Neolithic samples, those from Ajvide, Visby, and Korsnäs (Figure 2), were recovered as isolated findings in cultural layers. One sample was from a complete skeleton found in a burial in Central Sweden (Bergsgraven in Linköping). The Medieval samples originated from isolated skeletal remains recovered in urban (Skara and Stockholm) or rural contexts (Eketorp, Sunnerby).

We used polymorphisms found within a 219 bp fragment of the dog D-loop region and comparison with previously published sequences to determine Hgs. To portray the relationship between sequences we constructed a reduced median network, including all 219 bp, using Network 4.1 [26]; threshold was set to 1 . The default parameters for reduction were used, where parallel mutations are assumed to be more frequent between existing sequences, than between an existing sequence and a median vector. As the reduction was intense, a NJ tree was constructed to support the network using the Kimura 2-parameter model of sequence evolution. Support for the nodes was assessed with 1000 bootstrap pseudoreplicates.

The Hg frequencies within the ancient datasets were compared to those in modern Scandinavian dogs [9] using $\chi^{2}$ tests. To ensure a minimum sample of 5 for all cells in $\chi^{2}$ tests, we pooled Hgs A and D, and C and B (following the best natural grouping according to the network, Figure 1). Finally, we used the binomial distribution to estimate the probability of observing as many sequences from $\mathrm{Hg} \mathrm{D}$ as found in the ancient samples assuming that the relative frequency was the same as in modern native Scandinavian dogs.

\section{Authors' contributions}

HM did all experimental work apart from the independent replications, and helped analyse the data and write the paper. CV did part of the analytical work, and helped write the paper. TG and EW did the independent replication. TG revised the language. JS did the morphological selection, and described the archaeology. GH supervised the experimental work. AG did the analytical work together with $\mathrm{HM}$ and $\mathrm{CV}$, and wrote the paper together with $\mathrm{HM}$ and $\mathrm{CV}$. All authors read and approved the final manuscript.

\section{Acknowledgements}

We thank L. Drenzel at the Museum of National Antiquities, M. Douglas at Östergötland County Museum, M. Vretemark at Västergötlands Museum and $A$. Nyqvist Thorsson at Väner Museum for supplying bone samples, $L$. Tomasson for constructing Figure 2 and J. Leonard for valuable comments. The Swedish Research Council provided financial support for the study.

\section{References}

I. Hewitt GM: Genetic consequences of climatic oscillations in the Quaternary. Philos Trans R Soc Lond B Biol Sci 2004, 359( I 442): I 83-95; discussion 195.

2. Leonard JA, Wayne RK, Wheeler J, Valadez R, Guillen S, Vila C: Ancient DNA evidence for Old World origin of New World dogs. Science 2002, 298(5598): 1613-1616.

3. Karlsson AO, Wallerstrom T, Gotherstrom A, Holmlund G: Y-chromosome diversity in Sweden - a long-time perspective. Eur J Hum Genet 2006, I 4(8):963-970.

4. Pakendorf B, Stoneking M: Mitochondrial DNA and human evolution. Annu Rev Genomics Hum Genet 2005, 6: I 65-I83.

5. Semino O, Passarino G, Oefner PJ, Lin AA, Arbuzova S, Beckman LE, De Benedictis G, Francalacci P, Kouvatsi A, Limborska S, Marcikiae M, Mika A, Mika B, Primorac D, Santachiara-Benerecetti AS, CavalliSforza LL, Underhill PA: The genetic legacy of Paleolithic Homo sapiens sapiens in extant Europeans: a $\mathbf{Y}$ chromosome perspective. Science 2000, 290(5494): I I55-I I 59.

6. Thomas MG, Parfitt T, Weiss DA, Skorecki K, Wilson JF, le Roux M, Bradman N, Goldstein DB: Y chromosomes traveling south: the cohen modal haplotype and the origins of the Lemba--the "Black Jews of Southern Africa". Am J Hum Genet 2000, 66(2):674-686.

7. Notter DR: The importance of genetic diversity in livestock populations of the future. J Anim Sci 1999, 77(I):6I-69.

8. Vila C, Savolainen P, Maldonado JE, Amorim IR, Rice JE, Honeycutt RL, Crandall KA, Lundeberg J, Wayne RK: Multiple and ancient origins of the domestic dog. Science 1997, 276(53 I9): I687-I689.

9. Angleby $\mathrm{H}$, Savolainen P: Forensic informativity of domestic dog mtDNA control region sequences. Forensic Sci Int 2005, I 54(23):99-110.

10. Pires AE, Ouragh L, Kalboussi M, Matos J, Petrucci-Fonseca F, Bruford MW: Mitochondrial DNA sequence variation in Portuguese native dog breeds: diversity and phylogenetic affinities. J Hered 2006, 97(4):318-330.

II. Savolainen P, Zhang YP, Luo J, Lundeberg J, Leitner T: Genetic evidence for an East Asian origin of domestic dogs. Science 2002, 298(5598): $1610-1613$.

12. Jansen T, Forster P, Levine MA, Oelke H, Hurles M, Renfrew C, Weber J, Olek K: Mitochondrial DNA and the origins of the domestic horse. Proc Natl Acad Sci U S A 2002, 99(16): 10905-10910.

13. Arnesson Westerdahl A: Mesolitiskt hundfynd vid Hornborgasjön. Värdefulla fauna- och domestikationshistoriska fynd. Flora och Fauna 1983, 78:21 I-216.

14. Magnell O: Tracking Wild Boar and Hunters. Osteology of Wild Boar in Mesolithic South Scandinavia. In Acrhaeology Lund , Lund; 2005.

15. Benecke N: Studies on Early Dog Remains from Northern Europe. Journal of Archaeological Science 1987, I 4(3 I-49):.

16. Pluskowski A: Where are the Wolves? Investigating the Scarcity of Eurasian Grey Wolf (Canis lupus lupus) Remains in 
Medieval Archaeological Contexts and its Implications. International Journal of Osteoarchaeology 2006, 16:279-295.

17. Jonsson L: The Vertebrate Faunal Remains from the Late Atlantic Settlement Skateholm in Scania, South Sweden. In The Skateholm Project I, Man and Environment Edited by: Larsson L. Stockholm , Almqvist \& Wiksell International.; 1988:56-89.

18. Verginelli F, Capelli C, Coia V, Musiani M, Falchetti M, Ottini L, Palmirotta R, Tagliacozzo A, De Grossi Mazzorin I, Mariani-Costantini R: Mitochondrial DNA from prehistoric canids highlights relationships between dogs and South-East European wolves. Mol Biol Evol 2005, 22(I 2):254I-255।.

19. Gotherstrom A, Anderung C, Hellborg L, Elburg R, Smith C, Bradley DG, Ellegren $\mathrm{H}$ : Cattle domestication in the Near East was followed by hybridization with aurochs bulls in Europe. Proc Biol Sci 2005, 272( ( 579):2345-2350.

20. Larson G, Dobney K, Albarella U, Fang M, Matisoo-Smith E, Robins J, Lowden S, Finlayson H, Brand T, Willerslev E, Rowley-Conwy P, Andersson L, Cooper A: Worldwide phylogeography of wild boar reveals multiple centers of pig domestication. Science 2005, 307(57|5): 1618-162|.

21. Svensson EM, Anderung C, Baubliene J, Persson P, Malmstrom H, Smith C, Vretemark M, Daugnora L, Gotherstrom A: Tracing genetic change over time using nuclear SNPs in ancient and modern cattle. Anim Genet 2007.

22. Vila C, Seddon J, Ellegren H: Genes of domestic mammals augmented by backcrossing with wild ancestors. Trends Genet 2005, 2 I(4):2।4-2।8.

23. Valadez R, Mestre G: Historia del Xoloitzcuintel en México. México City, Universidad nacional Autónoma de México; 1999.

24. Malmstrom H, Stora J, Dalen L, Holmlund G, Gotherstrom A: Extensive human DNA contamination in extracts from ancient dog bones and teeth. Mol Biol Evol 2005, 22(10):2040-2047.

25. Malmstrom H, Svensson EM, Gilbert MT, Willerslev E, Gotherstrom A, Holmlund G: More on contamination: the use of asymmetric molecular behavior to identify authentic ancient human DNA. Mol Biol Evol 2007, 24(4):998-I004.

26. Bandelt HJ, Macaulay V, Richards M: Median networks: speedy construction and greedy reduction, one simulation, and two case studies from human mtDNA. Mol Phylogenet Evol 2000, 16(1):8-28.

\section{Publish with Bio Med Central and every scientist can read your work free of charge}

"BioMed Central will be the most significant development for disseminating the results of biomedical research in our lifetime. "

Sir Paul Nurse, Cancer Research UK

Your research papers will be:

- available free of charge to the entire biomedical community

- peer reviewed and published immediately upon acceptance

- cited in PubMed and archived on PubMed Central

- yours - you keep the copyright

Submit your manuscript here:

http://www.biomedcentral.com/info/publishing_adv.asp
BiolMedcentral 